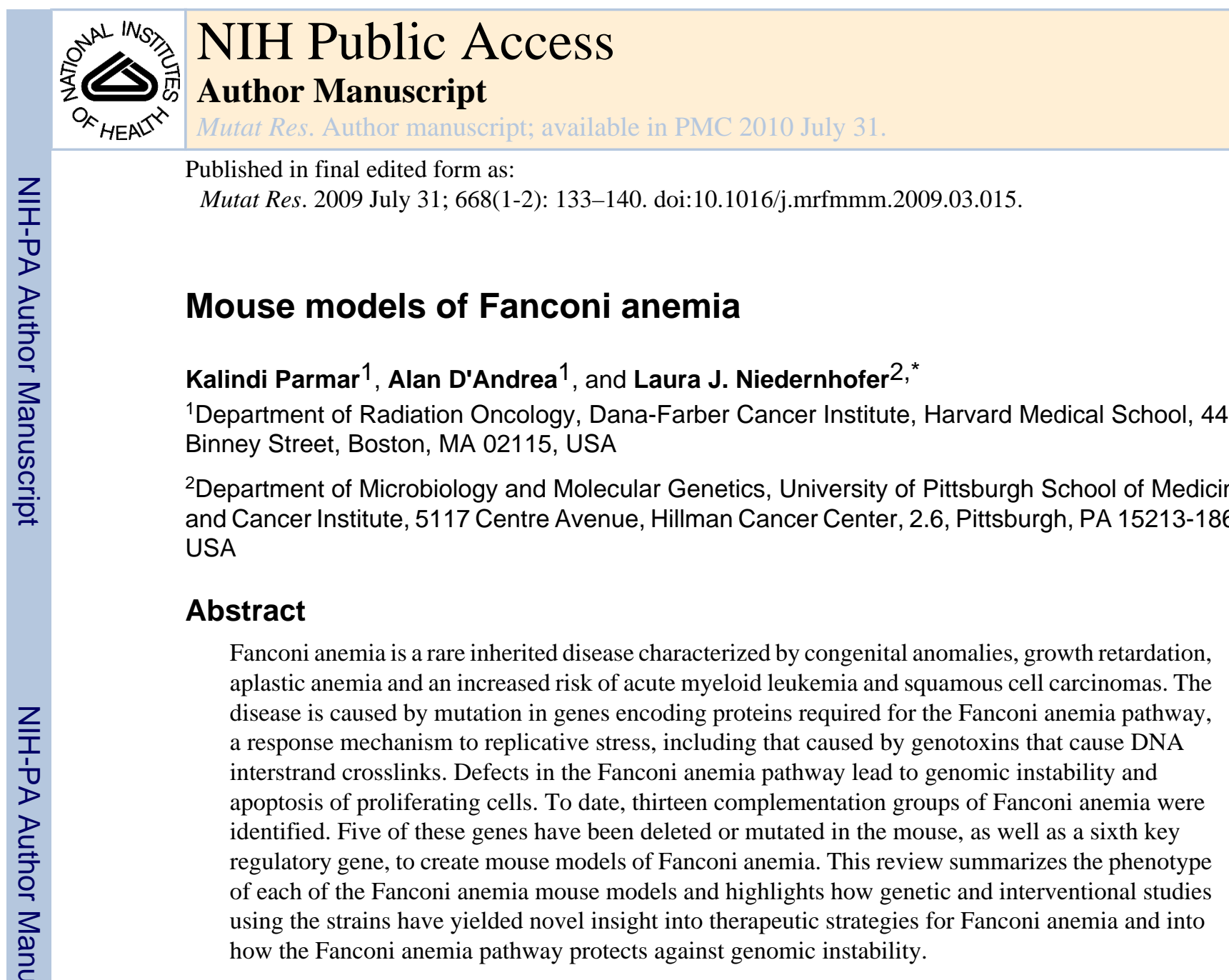

\title{
Keywords
}

interstrand crosslinks; gene targeting; mouse models; genome instability; tumors; stem cells

\section{Fanconi anemia}

Fanconi anemia is a rare autosomal recessive disease with a complex spectrum of symptoms including congenital skeletal and renal anomalies, growth retardation, pigmentation abnormalities, fertility defects, aplastic anemia, and increased risk of acute myeloid leukemia and epithelial tumors (see "Fanconi Anemia and its Diagnosis" Auerbach, this issue).

Progressive bone marrow failure and late-developing myeloid malignancies account for $90 \%$ of mortality in FA patients. Bone marrow failure in FA children is attributed to the excessive apoptosis and subsequent failure of the hematopoietic stem cell compartment. The disease is caused by mutation in genes encoding proteins required for the Fanconi anemia (FA) pathway, a response mechanism to replicative stress (33). To date, thirteen complementation groups of FA have been identified (FANC-A, B, C, D1, D2, E, F, G, I, J, L, M, N) (63). FA is diagnosed

\footnotetext{
*Corresponding author: Laura J. Niedernhofer, Department of Microbiology and Molecular Genetics, University of Pittsburgh School of Medicine, University of Pittsburgh Cancer Institute, 5117 Centre Avenue, Hillman Cancer Center, Research Pavilion 2.6, Pittsburgh, PA 15213-1863 USA, Phone: 412-623-7763, Fax: 412-623-7761, niedernhoferl@upmc.edu.

The authors declare that there are no conflicts of interest.

Publisher's Disclaimer: This is a PDF file of an unedited manuscript that has been accepted for publication. As a service to our customers we are providing this early version of the manuscript. The manuscript will undergo copyediting, typesetting, and review of the resulting proof before it is published in its final citable form. Please note that during the production process errors may be discovered which could affect the content, and all legal disclaimers that apply to the journal pertain.
} 
by clinical suspicion coupled with detecting an increased number of chromosomal aberrations in patient cells exposed to drugs that induce DNA interstrand crosslinks (ICLs). ICLs covalently tether both strands of the DNA helix together and therefore are an absolute block to the progression of a replication fork and a potent inducer of replication stress. Crosslinking agents induce replication-dependent double-strand breaks (DSBs) (54). These DSBs are subsequently repaired by homologous recombination (HR), which is detected cytogenetically as sister chromatid exchanges (the swapping of sister chromatids distal to a DSB) (see "Cellular and molecular consequences of defective Fanconi anemia proteins in replication-coupled DNA repair: mechanistic insights" Thompson, this issue). The diagnosis of FA is made when crosslinking agents cause chromatid breaks and radial structures rather than sister chromatid exchanges. These hallmark cytogenetic changes demonstrate that HR-mediated repair of ICLs is compromised in FA.

\section{Fanconi anemia pathway}

The thirteen FA proteins work as a complex signaling network that facilitates HR-mediated repair of DSBs caused by DNA ICLs and other types of replication stress (see "The Genetic and Molecular Basis of Fanconi Anemia" de Winter and Joenje, this issue for more detail and a model). FANC A, B, C, E, F, G, L and M interact to form the FA core complex (19). The FANCL subunit is an E3 ubiquitin ligase that monoubiquitylates FANCD2 and FANCI during $\mathrm{S}$ phase, particularly in response to genotoxic stress (48). After ubiquitylation, FANCD2 is stabilized on chromatin with numerous proteins required for HR including FANCD1/BRCA2 and the FA core complex (80).

Three genes encoding components of the FA core complex have been deleted in the mouse (FancA, Fanc C and FancG), as well as FancDl and FancD2 (18). Most recently, the gene that encodes the enzyme that deubiquitylates FANCD2, Usp1, was deleted in the mouse (36), yielding the most accurate recapitulation of FA. This review summarizes the phenotype of the various FA mouse models (see Table 1) and illustrates how genetic and interventional studies using the mice have revealed important information about how the FA pathway protects against genomic instability and how FA might be treated.

\section{FancA ${ }^{-/-}$mice}

Unlike FA patients, FancA $^{-/-}$mice, created by deletion of exons 4-7, do not spontaneously display congenital anomalies or severe hematological abnormalities. (12). However, $F_{\text {FancA }}{ }^{-/-}$mice do have significantly reduced fertility due to hypogonadism (12). Despite the mild phenotype, mouse embryonic fibroblasts (MEFs), derived from these mice are hypersensitive to mitomycin $\mathrm{C}$ (MMC) and accumulate large numbers of chromosomal aberrations in response to MMC (12), hallmark diagnostic criteria of FA (see "Fanconi Anemia and its Diagnosis" Auerbach, this issue). These $\mathrm{FancA}^{-/-}$mice have a mild, but significant thrombocytopenia, corresponding with impaired proliferation of bone marrow-derived megakaryocyte progenitors, but not granulocyte-macrophage progenitors, in vitro (66). No differences are seen in number of mature or progenitor bone marrow, spleen or thymic cells between wild type and $\mathrm{FanCA}^{-/-}$mice (66). However, cells isolated from the bone marrow of $\mathrm{FancA}^{-/-}$mice proliferate poorly under growth stimulatory conditions due to increased apoptosis (66). To date, a (possible) hematopoietic stem cell defect for these $\mathrm{FancA}^{-/-}$mice has not yet been examined through serial transplant studies. Despite the lack of behavioral abnormalities, FancA $^{-/-}$and Fanc $^{-/-}$mice (see below) have microcephaly due to increased neuronal apoptosis (74). Apoptosis and chromosomal instability occurs in proliferating cells and not post-mitotic neurons and leads to a progressive loss of neural stem and progenitor cells with aging (74). This can be interpreted as accelerated aging of stem cells in FA (73). 
FancA $^{-/-}$mice, created by deletion of exons 1-6, display prenatal growth retardation and craniofacial abnormalities (microphthalmia), common features of FA (83). These developmental defects are strain-dependent, indicating the existence of modifier genes affecting the severity of the phenotype. Both strains of $\mathrm{FancA}^{-/-}$mice have impaired fertility (83). The more severe phenotype of this knock-out strain corresponds to an increased hypersensitivity of bone marrow progenitors to MMC relative to those isolated from the other Fanc $^{-/-}$strain $(66,83)$. This supports the notion that the clinical heterogeneity in FA results at least in part from differences in sensitivity to crosslink damage.

$\mathrm{FancA}^{-/-}$mice are not hypersensitive to ionizing radiation (10). In contrast, mice defective in proteins required for HR-mediated DSB repair (e.g. RAD54 or BRCA1) are hypersensitive to ionizing radiation $(14,71)$. This suggests that FA is not caused by a generalized defect in HR, although some HR defects in these mice may be cell type specific. In contrast, cells with a different targeted deletion in FancA show impaired gene targeting due to a defect in singlestrand annealing (87), providing evidence that the FA pathway may facilitate a subpathway of HR.

\section{Fanc $C^{/-}$mice}

Like the $\mathrm{FancA}^{-/-}$mice, genetic deletion of $\mathrm{FancC}$ in the mouse does not lead to skeletal abnormalities or spontaneous peripheral hematological abnormalities $(11,82)$. However, $\mathrm{FancC}^{-1-}$ mice are born with sub-Mendelian frequency and have a significantly increased incidence of microphthalmia, a congenital abnormality, if they are bred into a C57BL/6J background (6). FancC $^{-/-}$mice have impaired fertility (82) due to impaired proliferation of germ cells during embryogenesis (51), similar to FA in humans. An increased incidence of tumors in $\mathrm{FancC}^{-/-}$mice, greater than $1 \mathrm{yr}$ of age, as been reported (6).

As predicted from FA, hematopoietic progenitor cells isolated from $\mathrm{FancC}^{-/-}$mice have impaired function in vitro (82), as do hematopoietic stem cells (7). Mouse embryonic fibroblasts, derived from these mice are hypersensitive to MMC and diepoxybutane (DEB) (82) and stimulated splenocytes isolated from $\mathrm{FancC}^{-/-}$mice arrest in G2/M and display a 6fold increase in chromosomal aberrations in response to crosslinking agents $(11,82)$, hallmark diagnostic criteria for FA (see "Fanconi Anemia and its Diagnosis" Auerbach, this issue). Both male and female $\mathrm{FancC}^{-/-}$mice have reduced fertility due to impaired gametogenesis $(11,82)$. Bone marrow progenitor cells isolated from adult, but not juvenile $\mathrm{FancC}^{-/-}$mice have impaired proliferation in vitro (82), demonstrating a progressive, yet subclinical hematopoietic defect. This is substantiated by the observation that bone marrow cells isolated from $\mathrm{FancC}^{-/-}$mice have a significantly decreased short-term and long-term, multi-lineage repopulating ability in competitive transplantation assays $(4,7,27)$. This was attributed to impaired ability of Fanc $^{-/-}$hematopoietic stem cells to differentiate and self-renew in response to stimulatory growth factors and cytokines $(3,23)$. The defect in repopulating capacity of $\mathrm{FancC}^{-/}$bone marrow cells is corrected by retroviral-mediated gene transfer of FancC (28), demonstrating that FANCC and the FA pathway are specifically required for the maintenance of HSC function in vivo.

Like the $\mathrm{FancA}^{-/-}$mice, the relatively mild phenotype of $\mathrm{FancC}^{-/-}$mice is remarkable in view of the fact that: 1) the cellular defect in $\mathrm{FancA}^{-/-}$and $\mathrm{FancC}^{-/-}$MEFs is similar to that of FA cells $(11) ; 2)$ the mouse genes correct human FA cells of the same complementation group, demonstrating conservation of function between mice and humans $(79,81,84) ; 3)$ FancA and Fanc $C$ are highly expressed in mouse embryos in tissues prone to developmental defects in FA $(1,38)$; 4) Fanc $^{-/-}$mice are hypersensitive to crosslinking agents (8) and chronic in vivo exposure to a low dose of MMC induces chromosomal aberrations and progressive bone marrow failure with pancytopenia $(26,58,62,82)$. Clearly mice defective in the FA pathway, 
like humans, are hypersensitive to DNA interstrand crosslinks, leading to the possibility that the mild phenotype in mice could be due to fewer spontaneous DNA lesions. This could be because of differences in metabolism between mice and humans, leading to fewer spontaneous crosslinks. For instance, humans may develop higher levels of endogenous crosslinking compounds, such as formaldehyde (64) or malondialdehyde (53). Alternatively, and more plausibly, it is because experimental mice are bred in a bland environment consisting of a uniform, controlled diet and sterile housing material, presenting minimal exogenous genotoxic challenge. The implications of this are that much of the DNA damage that drives the FA phenotype may be environmental and therefore preventable.

\section{Fanc $G^{-/}$mice}

The phenotype of $\mathrm{FancG}^{-/-}$mice is virtually identical to that of $\mathrm{FancA}^{-/-}$and $\mathrm{FancC}^{-/-}$mice (18). Fanc $^{-/-}$mice lack the characteristic congenital anomalies characteristic of FA and do not spontaneously develop hematological abnormalities or spontaneous cancer in the first year of life (37). Like FancA ${ }^{-/-}$and Fanc $^{-/-}$mice, Fanc $^{-/-}$mice have reduced fertility due to impaired gametogenesis $(37,86)$, a characteristic of FA (see "Fanconi Anemia and its Diagnosis" Auerbach, this issue). Primary MEFs isolated from Fanc $^{-/-}$mice display increased spontaneous and MMC-induced chromosomal aberrations relative to wild type MEFs (37). Furthermore, stimulated splenic lymphocytes from $\mathrm{FancG}^{-/-}$mice display increased chromosomal aberrations in response to DEB and MMC and MMC-treated bone marrow progenitor cells have significantly impaired proliferation (86). This growth defect is not due to accelerated telomere attrition, since $\mathrm{Fanc}^{-/-}$hematopoietic stem cells, lymphocytes and MEFs, as well as FA-G human fibroblasts, have normal telomere maintenance even if cultured in the presence of MMC (16). Interestingly, Li et al., recently demonstrated that mesenchymal/ progenitor stem cells from the bone marrow of $\mathrm{Fanc}^{-/-}$mice have a proliferation defect and an impaired ability to promote engraftment of hematopoietic stem cells (43). This demonstrates that not only the hematopoietic cells but the microenvironment of the bone marrow are affected in FA.

\section{FancD1/Brca2/- mice}

FANCD1 is identical to BRCA2 (34). FANCD1/BRCA2 interacts with RAD51 (45) and is required for HR-mediated repair of DNA DSBs $(49,78)$. In humans, hapoloinsufficiency of BRCA2 leads to a dramatically increased risk of breast, ovarian and pancreatic cancer. Genetic deletion of FancD1/Brca2 in the mouse results in embryonic lethality (70). Homozygous deletion of exon 27 of FancD1/Brca2 prevents the interaction of FANCD1/BRCA2 with FANCD2 (2). Hematopoietic cell function is significantly compromised in FancDI/ $B r c a 2^{\Delta 27 / \Delta 27}$ mice, including progenitor cell proliferation, HSC self-renewal and competitive repopulation capacity (52). However the number and types of cells in the peripheral blood, spleen, thymus or bone marrow of adult FancD $1 / B r c a 2^{\Delta 27 / \Delta 27}$ mice is normal, meaning that the mice do not recapitulate the aplastic anemia characteristic of FA. Despite this, there are several indications that the hematopoietic phenotype of FancDI/Brca $2^{\Delta 27 / \Delta 27}$ mice is more severe than that of other FA models (Table 1). Unlike $\mathrm{FancA}^{-/-}$mice, bone marrow cells from FancD $1 / B r c a 2^{\Delta 27 / \Delta 27}$ mice display spontaneous chromosomal aberrations and are more sensitive to the crosslinking agent MMC (52). Furthermore, spontaneous loss of hematopoietic cells (colony forming cells) occurs earlier in FancD 1/Brca $2^{\Delta 27 / \Delta 27}$ mice than in FancA $^{-/-}$or Fanc $^{-/-}$mice $(7,52,66,82)$. This is consistent with the fact that FANCD1 operates downstream of FANCA and FANCC in the FA pathway and that FANCD1 is more critical for the repair of replication-stalling lesions than the FA core complex.

In support of this, FA-D1 cells are the only FA complementation group in which RAD51 foci do not form in response to ionizing radiation and crosslink damage $(20,21,77)$, demonstrating 
that HR-mediated DSB repair is dependent upon FANCD1/BRCA2 but not the FA core complex. Accordingly, FancD1/Brca2 $2^{\Delta 27 / \Delta 27}$ mice are hypersensitive to ionizing radiation (52). However, FancD $1 / B r c a 2^{\Delta 27 / \Delta 27}$ mice do not have a defect in gametogenesis or impaired fertility (2), indicating that the interaction of FANCD1 with FANCD2 is important for HRmediated repair of DNA damage, but not meiosis.

In addition to hematopoietic defects, $F a n c D 1 / B r c a 2^{\Delta 27 / \Delta 27}$ mice are prone to epithelial tumors, including gastric cancer and squamous cell carcinomas (47). Thus the FancD1/Brca2 ${ }^{\Delta 27 / \Delta 27}$ mice mimic the cancer predisposition syndrome of carriers of BRCA2 mutations as well as many aspects of the hematopoietic defects of FA.

\section{FancD2/- mice}

FancD2 $2^{-/-}$mice are viable (32), indicating that FANCD2 is not required for mammalian development. FancD $2^{-/-}$mice are born with sub-Mendelian frequency and display pre- and post-natal growth retardation. The severity of the phenotype of the mice is dependent upon their genetic background, with a more severe phenotype emerging in C57BL/6J than in 129S4, indicating the existence of modifying loci. Like $\mathrm{FancA}^{-/}$, $\mathrm{FancC}^{-\mathrm{I}^{-}}$and $\mathrm{FancG}^{-\mathrm{I}^{-}}$mice and FA patients, cells from $\mathrm{FancD}^{-/-}$mice are hypersensitive to crosslinking agents and the mice show hypogonadism with impaired gametogenesis (Table 1). The majority of $\mathrm{FancD2}^{-/-}$mice in a C57BL/6J background have microphthalmia due to impaired development of the lens and retina (32). FancD $2^{--}$mice have a significantly increased incidence of tumors including ovarian, gastric and hepatic adenomas as well as hepatocellular, lung, ovarian and mammary carcinomas (32). The tumor spectrum, including primarily epithelial tumors is similar to FancDI/ $\mathrm{BrCa}^{-/-}$mice and BRCA2 patients.

The phenotype of these mice is modestly more severe than that of mice genetically deleted for the FA core complex proteins (FANCA, $-\mathrm{C}$ or $-\mathrm{G}$ ), suggesting that FANCD2 has some activity even in the absence of activation by the FA core. FancD $2^{-/-}$mice are mildly hypersensitive to ionizing radiation (32), indicating a role, albeit non-essential, in protecting against oxidative stress or DNA DSBs, which appears to be independent of the FA core complex. This is consistent with the observation that RAD51 foci formation, an essential step in HR-mediated repair of DNA DSBs, requires FANCD1/BRCA2, but not FANCD2 (21). Recently, using a retroviral insertional mutagenesis, a mouse model for FancD2 was generated in our laboratory. Similar to the FancD2 $2^{-/}$mouse model reported by Houghtaling et al. (32), the FancD2 ${ }^{-/-}$strain developed in our laboratory display FA phenotypes including cellular hypersensitivity to $\mathrm{MMC}$, hypogonadism and reduced fertility. In addition, bone marrow from $\mathrm{FancD2}^{-I_{-}}$mice exhibit hematopoietic stem cell defects, including reduced numbers and long-term repopulating ability (Parmar et al, unpublished data).

\section{Usp1-/- mice}

The deubiquitylating enzyme, USP1 (ubiquitin-specific protease 1), was recently demonstrated to regulate the level of monoubiquitylated FANCD2 and FANCI proteins $(55,76)$. Inhibition of Uspl by siRNA knockdown in human cell lines leads to an accumulation of monoubiquitylated isoforms of FANCD2 and FANCI proteins. Unexpectedly, disruption of Uspl in chicken DT40 cells results in hypersensitivity to DNA interstrand crosslinking agents, similar to that observed in cells with mutations in FA genes (57). USP1 is not an FA gene per se, since no human FA patients have been observed to carry germ line mutations in the USP1 gene. Thus to further understand the biological significance of USP1, we recently generated a Uspl knockout mouse (36).

Interestingly, $U s p 1^{-/-}$mice share many phenotypic features with other FA gene knockout mice (Table 1). Usp $1^{-/-}$mice are small, have decreased fertility and display cellular hypersensitivity 
to MMC and other crosslinking agents. The mice exhibit significant perinatal lethality and $80 \%$ of $U s p 1^{-/-}$mice die from cyanosis in the perinatal period (36). MEFs derived from Usp $1^{-/-}$ embryos have been particularly useful in examining the function of the USP1 in the FA pathway. Usp 1 $1^{-/}$MEFs have a bonafide defect in HR. Also, although the level of monoubiquitylated FANCD2 protein is normal in $U s p 1^{-/-} \mathrm{MEFs}$, it is not assembled in DNA repair foci (36). This indicates that FANCD2 must be coordinately monoubiquitylated by the FA core complex and deubiquitylated by USP1 for efficient assembly of the protein into nuclear complexes to facilitate DNA repair.

Finally, Usp ${ }^{-/-} ; F_{a n c d 2} 2^{-/-}$mice were generated (36). Double knockout mice are viable, but primary cells derived from them are hypersensitive to MMC relative to either single knockout. These results provide critical evidence that the Uspl gene may have additional functions outside of the classical FA pathway that facilitates the repair or tolerance of genotoxic stress. Consistent with this, recent studies indicate that USP1 regulates the level of monoubiquitylated PCNA, suggesting that it is also an important modulator of translesion DNA synthesis, a mechanism that facilitates DNA damage tolerance (35).

\section{Genetic studies: double mutant mice}

FancA $^{-1-} ; \mathrm{FancC}^{-/-}$mice and cells derived from them are phenotypically identical to single mutants (56). This provides crucial genetic evidence that FANCA and FANCC are epistatic. Fanc $^{-/-}$mice were crossed into a Sod $1^{-/-}$background to delete $\mathrm{Cu} / \mathrm{Zn}$ superoxide dismutase and increase endogenous oxidative stress (25). The double mutant mice display bone marrow hypocellularity due to a loss of committed progenitor cells, resulting in anemia and leucopenia. FancC $^{-/-} ;$Sodl $^{-/-}$bone marrow progenitor cells proliferate poorly in vitro. These data provide experimental evidence that oxidative stress contributes to bone marrow failure in FA.

In other studies, $\mathrm{FancC}^{-1-}$ were crossed into a p53-deficient background to determine if ablation of p53-dependent apoptosis caused tumorigenesis (17). Fanc $^{-/} ; p 53^{-/-}$mice develop spontaneous tumors more rapidly than $p 53^{-/-}$mice (median survival 105 and 185 days, respectively). This confirms that FANCC and the FA pathway act to suppress tumorigenesis. Importantly, Fanc $^{-/-} ; p 53^{-/-}$mice and $\mathrm{FancC}^{-\mathrm{C}^{-}} ; \mathrm{p} 53^{+/-}$mice displayed a wide variety of tumors including sarcomas, lymphomas and adenocarcinoma, whereas $p 53^{-/-}$mice are prone to thymic lymphomas (17). Many of the tumor types seen in $\mathrm{FancC}^{--}$;p53-deficient mice are also seen in FA patients in addition to the syndrome's most common cancer which is acute myeloid leukemia (see "Fanconi Anemia and its Diagnosis" Auerbach, this issue). Therefore these double mutant animals provide a good animal model for identifying strategies to prevent malignancies in FA.

FancD $2^{-/-} p 53^{+/-}$mice also have a significantly increased incidence of tumors relative to either single mutant strain (30). Tumors were detected significantly earlier in female double mutant animals compared to controls (approximately 13 vs. $15 \mathrm{mths}$ of age). The tumor spectrum includes sarcomas typical of p53-deficient mice and epithelial tumors seen in $\mathrm{FancD}^{-/-}$mice. The median survival of FancD2 $2^{-/} p 53^{+/-}$than $\mathrm{FancC}^{-/-} p 53^{+/-}$mice is similar $(\sim 1 \mathrm{yr})$, but the tumor spectrum is vastly different, with approximately a third of the former having adenocarcinomas, while the latter have exclusively lymphomas and sarcomas $(17,30)$. Abrogation of p53 expression in FancD2 $2^{-/-}$MEFs prevents arrest of the cells in S phase in response to genotoxic stress (30). This demonstrates that p53-dependent cell cycle arrest occurs even if the FA pathway is not activated in response to DNA damage and that this arrest is important for cancer protection.

Prkdc encodes the catalytic subunit of DNA-PK, an essential protein for non-homologous endjoining repair (NHEJ) of DNA DSBs. Nonsense mutations in Prkdc affect DNA-PK activity 
and lead to severe-combined immunodeficiency (5). FANCD2 is implicated in HR-mediated DSB repair. FancD2 $2^{-/-}$mice were crossed into a Prkdc $c^{\text {sc/sc }}$ background, and the double knockout mice were discovered to be even more sensitive to ionizing radiation than either single mutant strain (31). This supports a role for FANCD2 in HR-mediated repair of DNA DSBs and not NHEJ. The tumor incidence in these mice was not reported.

\section{Interventional studies to elucidate the function of the FA pathway}

$\mathrm{FancC}^{-/-}$mice chronically exposed to a sublethal dose of the crosslinking agent MMC develop progressive pancytopenia due to bone marrow failure (8), identical to the spontaneous symptoms of FA. MMC exposure depletes the bone marrow of CD34+ cells, but not CD34(7), suggesting that early hematopoietic progenitors are particularly vulnerable to crosslink damage. Fanc $C^{-/-}$mice chronically treated with MMC offer a good model in which to study therapeutic interventions for FA. Transplantation of these mice with $\mathrm{FancC}^{-/-}$bone marrow cells transduced with FANCC cDNA corrected pancytopenia, (22). Similar results were achieved by correcting $\mathrm{FancA}^{-/-}$hematopoietic stem cells using a lentiviral vector and using a limited dilution of the transduced cells to correct the hematopoietic defect in MMC-treated $F_{\text {Fanc }}{ }^{-/-}$mice (85). This model was also used to test whether or not cytokines can be used to treat bone marrow failure in FA (9). G-CSF by itself or in combination with erythropoietin delayed the onset of pancytopenia in $\mathrm{FancC}^{-/-}$mice chronically treated with MMC, but was unable to prevent bone marrow failure.

Haneline et al. demonstrated that correction of $\mathrm{FancC}^{-/}$hematopoietic stem cells with Fanc $C$ cDNA restored the repopulating capacity of these cells in a competitive bone marrow transplantation assay (28). Interestingly, the negative control for this experiment, uncorrected Fanc $^{-/-}$mouse bone marrow, revealed important mechanistic information about FA. Ex vivo culture of $\mathrm{FancC}^{-/-}$mouse cells prior to bone marrow transplantation caused an increase in the incidence of hematological abnormalities in recipient mice, including bone marrow failure, myelofibrosis, splenomegaly, myelodysplastic syndrome, myeloproliferative disease and acute myeloid leukemia, all characteristic of FA $(28,40)$. Culture of FancC $^{-/-}$mouse bone marrow also led to a time-dependent increase in cytogenetic abnormalities, apoptosis and the emergence of a cell population that is resistant to pro-apoptotic cytokines. This provides experimental evidence that the hematological abnormalities in FA arise because the bone marrow cells are proliferating under stress, leading to clonal selection of cells with growth advantage. The incidence of hematologic abnormalities is further exacerbated if the $\mathrm{FancC}^{-/-}$ mouse bone marrow cells are exposed to the immunoregulatory cytokine TNF- $\alpha$ (39), and TNF- $\alpha$ levels have been reported to be elevated in the bone marrow of FA patients $(13,67$, $68)$.

There is also evidence that cells isolated from FA mice are hypersensitive to oxidative stress. Bone marrow progenitor cells isolated from $\mathrm{FancC}^{-/-}$mice undergo premature replicative senescence when exposed to repetitive hypoxia-hyperoxia conditions (89). Exposure of $\mathrm{FancC}^{-/-}$hematopoietic progenitor cells to TNF- $\alpha$ in vitro negatively affects clonogenic proliferation and competitive hematopoietic repopulation, but this can be blocked by the ROS scavenger N-acetyl-L-cysteine (NAC) (69). Similarly, exposure of $\mathrm{FancC}^{-/-}$mice to TNF- $\alpha$ induces ROS production, oxidative DNA damage, chromosomal aberrations and premature replicative senescence in hematopoietic stem cells, which is alleviated by pre-treating the mice with NAC (91). These data suggest that much of the hypersensitivity of FA cells to proinflammatory cytokines is driven by oxidative stress. In addition, primary cells and tissue from $\mathrm{FancA}^{-/-}$mice are hypersensitive to oxidative stress in vitro and in vivo, as demonstrated by persistent overactivation of p53 (61). 
This is further supported by a recent study demonstrating that the radical scavenger, superoxide dismutase mimetic, Tempol, significantly delays the onset of cancer and increases survival of FancD $2^{-/} p 53^{+/-}$mice (88). Tumor-free survival was increased by $>25 \%$. These data provide strong evidence that endogenous oxidative stress plays a causative role in carcinogenesis in FA. Tempol had no adverse effect on the function of hematopoietic stem cells in competitive repopulating bone marrow transplantation out to six months. However, it is not clear, if the radical scavenger had a beneficial effect on hematopoietic stem cells.

\section{Utilizing the mouse models to discover therapeutic options for Fanconi anemia}

Hematological disease and malignancies are the most common cause of death in FA (see "Fanconi Anemia and its Diagnosis" Auerbach, this issue). This can be prevented by bone marrow transplantation, indicating that FA is a prime candidate disease for gene therapy (see "Finding the needle in the hay stack: Hematopoietic stem cells in Fanconi anemia", Muller and Williams, this issue, for more information on gene therapy in FA). Indeed, retroviral transduction of $\mathrm{FancA}^{-/-}$hematopoietic stem cells (lineage negative; Sca ${ }^{+}$) with human FANCA corrects the hypersensitivity of the hematopoietic stem cells to crosslink damage and their ex vivo proliferation defect (66), demonstrating the feasibility of gene therapy. Two major hurdles to gene therapy with autologous bone marrow transplant in FA are that: 1) patients are hypersensitive to cytotoxic agents used to condition the host for bone marrow engraftment and 2) hematopoietic stem cells isolated from FA patients are limited in number and hypersensitive to ex vivo culture conditions necessary for expansion. Solutions to both hurdles have been identified with FA mouse models. Transplantation of non-ablated $\mathrm{FancC}^{-/-}$mice with a 50:50 ratio of wild type and $\mathrm{FancC}^{-/-}$bone marrow cells leads to selective repopulation of hosts with wild type cells (27). Furthermore, lentivirus-mediated gene therapy with Brca2 was used to successfully treat $\mathrm{FancD} 1 / \mathrm{BrCa} 2^{\Delta 27 / \Delta 27}$ mice that were only mildly conditioned (65). This is because the genetically corrected hematopoietic stem cells have a selective growth advantage. These studies reveal that host bone marrow ablation with its associated toxicity may not be necessary in FA. In addition, Muller et al., recently demonstrated that "rapid" lentiviralmediated transduction of $\mathrm{FancA}^{-/-}$mouse hematopoietic stem cells, to minimize ex vivo manipulation of cells, resulted in engraftment levels equivalent to wild type cells (50). This offers great promise for autologous bone marrow transplantation to treat FA.

Interferon $\gamma(\mathrm{IFN}-\gamma)$ and TNF- $\alpha$ are immunoregulatory cytokines that inhibit cell proliferation and are implicated in the pathogenesis of aplastic anemia (44). $\mathrm{FancC}^{-/-}$mice have fewer $\mathrm{CD}^{+}$IFN- $\gamma$ secreting splenic lymphocytes (15). Fanc $^{-/-}$mice also display hypersensitivity to lipopolysaccharide-induced septic shock, resulting in prolonged anemia, leucopenia and bone marrow hypoplasia, as a well as enhanced secretion of pro-inflammatory cytokines (69). Fanc $^{-/-}$mouse and human FA-C hematopoietic progenitor cells are hypersensitive to IFN- $\gamma$ due to increased apoptosis $(26,42,58,59,62,82)$, as are FA-A and FA-G hematopoietic progenitor cells $(72,90)$. This is attributed to the fact that FANCA, FANCC and FANCG interact with heat shock protein 70 (HSP70) and the pro-apoptotic kinase dsRNA-dependent protein kinase PKR $(60,90)$. Mutations in any of these FA genes cause an accumulation of PKR in response to IFN- $\gamma$ and TNF- $\alpha$, which promotes apoptosis (90). Hypersensitivity to TNF- $\alpha$ is rescued by genetic deletion of p53, a downstream effecter of PKR (17), indicating that cytokine-induced apoptosis is p53-dependent. Alternatively, IFN- $\gamma$ hypersensitivity has been attributed to the induction of nitric oxide synthase (iNOS) (24). iNOS produces nitric oxide, a free radical that can stimulate lipid peroxidation (29), a potential source of endogenous DNA interstrand crosslink damage (53).

Experiments in mice demonstrated that IFN- $\gamma$ hypersensitivity can be exploited as a nongenotoxic method for myelopreparation to improve engraftment of hematopoietic stem 
cells $(42,72)$. Similarly, hematopoietic stem cells isolated from $\mathrm{FancA}^{-/-}, \mathrm{FancC}^{-/-}$and $\mathrm{FancD}^{-/-}$mice grown under hypoxic conditions $\left(1 \% \mathrm{O}_{2}\right)$ home to and engraft better in the bone marrow of myeloablated hosts (75).

\section{Summary}

In conclusion, FA mouse models now exist, resulting from targeted disruption of the FancA, FancC, Fanc G, FancD1, FancD2, or Usp1 gene. The mouse models exhibit some but not all of the developmental and hematologic manifestations of human FA patients (Table 1). While FA patients develop spontaneous hematologic failure, most FA mouse models have relatively normal hematologic function, though anemia can be elicited by in vivo exposure to crosslinking agents. Mouse models will be especially useful in the next few years for the assessment of chemoprotective agents, which limit oxidative stress, and the development of strategies to enhance the survival and expansion of FA hematopoietic stem cells with underlying DNA repair deficiency.

\section{Acknowledgments}

L.J.N. is supported by The Ellison Medical Foundation (AG-NS-0303-05) and NIEHS (R01 ES016114). K.P. and A.D.D. were supported by NIH grant U19AI067751.

\section{References}

1. Abu-Issa R, Eichele G, Youssoufian H. Expression of the Fanconi anemia group A gene (Fanca) during mouse embryogenesis. Blood 1999;94:818-24. [PubMed: 10397750]

2. Atanassov BS, Barrett JC, Davis BJ. Homozygous germ line mutation in exon 27 of murine Brca2 disrupts the Fancd2-Brca2 pathway in the homologous recombination-mediated DNA interstrand cross-links' repair but does not affect meiosis. Genes Chromosomes Cancer 2005;44:429-37. [PubMed: 16127665]

3. Aube M, Lafrance M, Charbonneau C, Goulet I, Carreau M. Hematopoietic stem cells from fancc(-/-) mice have lower growth and differentiation potential in response to growth factors. Stem Cells 2002;20:438-47. [PubMed: 12351814]

4. Battaile KP, Bateman RL, Mortimer D, Mulcahy J, Rathbun RK, Bagby G, Fleming WH, Grompe M. In vivo selection of wild-type hematopoietic stem cells in a murine model of Fanconi anemia. Blood 1999;94:2151-8. [PubMed: 10477746]

5. Blunt T, Gell D, Fox M, Taccioli GE, Lehmann AR, Jackson SP, Jeggo PA. Identification of a nonsense mutation in the carboxyl-terminal region of DNA-dependent protein kinase catalytic subunit in the scid mouse. Proc Natl Acad Sci U S A 1996;93:10285-90. [PubMed: 8816792]

6. Carreau M. Not-so-novel phenotypes in the Fanconi anemia group D2 mouse model. Blood 2004;103:2430. [PubMed: 14998919]

7. Carreau M, Gan OI, Liu L, Doedens M, Dick JE, Buchwald M. Hematopoietic compartment of Fanconi anemia group $\mathrm{C}$ null mice contains fewer lineage-negative CD34+ primitive hematopoietic cells and shows reduced reconstruction ability. Exp Hematol 1999;27:1667-74. [PubMed: 10560914]

8. Carreau M, Gan OI, Liu L, Doedens M, McKerlie C, Dick JE, Buchwald M. Bone marrow failure in the Fanconi anemia group C mouse model after DNA damage. Blood 1998;91:2737-44. [PubMed: 9531583]

9. Carreau M, Liu L, Gan OI, Hitzler JK, Dick JE, Buchwald M. Short-term granulocyte colonystimulating factor and erythropoietin treatment enhances hematopoiesis and survival in the mitomycin C-conditioned Fancc(-/-) mouse model, while long-term treatment is ineffective. Blood 2002;100:1499-501. [PubMed: 12149239]

10. Casado JA, Nunez MI, Segovia JC, Ruiz de Almodovar JM, Bueren JA. Non-homologous end-joining defect in fanconi anemia hematopoietic cells exposed to ionizing radiation. Radiat Res 2005;164:635-41. [PubMed: 16238440] 
11. Chen M, Tomkins DJ, Auerbach W, McKerlie C, Youssoufian H, Liu L, Gan O, Carreau M, Auerbach A, Groves T, Guidos CJ, Freedman MH, Cross J, Percy DH, Dick JE, Joyner AL, Buchwald M. Inactivation of $\mathrm{Fac}$ in mice produces inducible chromosomal instability and reduced fertility reminiscent of Fanconi anaemia. Nat Genet 1996;12:448-51. [PubMed: 8630504]

12. Cheng NC, van de Vrugt HJ, van der Valk MA, Oostra AB, Krimpenfort P, de Vries Y, Joenje H, Berns A, Arwert F. Mice with a targeted disruption of the Fanconi anemia homolog Fanca. Hum Mol Genet 2000;9:1805-11. [PubMed: 10915769]

13. Dufour C, Corcione A, Svahn J, Haupt R, Poggi V, Beka'ssy AN, Scime R, Pistorio A, Pistoia V. TNF-alpha and IFN-gamma are overexpressed in the bone marrow of Fanconi anemia patients and TNF-alpha suppresses erythropoiesis in vitro. Blood 2003;102:2053-9. [PubMed: 12750172]

14. Essers J, Hendriks RW, Swagemakers SM, Troelstra C, de Wit J, Bootsma D, Hoeijmakers JH, Kanaar R. Disruption of mouse RAD54 reduces ionizing radiation resistance and homologous recombination. Cell 1997;89:195-204. [PubMed: 9108475]

15. Fagerlie SR, Koretsky T, Torok-Storb B, Bagby GC. Impaired type I IFN-induced Jak/STAT signaling in FA-C cells and abnormal CD4+ Th cell subsets in Fancc-/- mice. J Immunol 2004;173:3863-70. [PubMed: 15356134]

16. Franco S, van de Vrugt HJ, Fernandez P, Aracil M, Arwert F, Blasco MA. Telomere dynamics in Fancg-deficient mouse and human cells. Blood 2004;104:3927-35. [PubMed: 15319283]

17. Freie B, Li X, Ciccone SL, Nawa K, Cooper S, Vogelweid C, Schantz L, Haneline LS, Orazi A, Broxmeyer HE, Lee SH, Clapp DW. Fanconi anemia type C and p53 cooperate in apoptosis and tumorigenesis. Blood 2003;102:4146-52. [PubMed: 12855557]

18. Friedberg EC, Meira LB. Database of mouse strains carrying targeted mutations in genes affecting biological responses to DNA damage Version 7. DNA Repair (Amst) 2006;5:189-209. [PubMed: 16290067]

19. Garcia-Higuera I, Taniguchi T, Ganesan S, Meyn MS, Timmers C, Hejna J, Grompe M, D'Andrea AD. Interaction of the Fanconi anemia proteins and BRCA1 in a common pathway. Mol Cell 2001;7:249-62. [PubMed: 11239454]

20. Godthelp BC, Artwert F, Joenje H, Zdzienicka MZ. Impaired DNA damage-induced nuclear Rad51 foci formation uniquely characterizes Fanconi anemia group D1. Oncogene 2002;21:5002-5. [PubMed: 12118380]

21. Godthelp BC, Wiegant WW, Waisfisz Q, Medhurst AL, Arwert F, Joenje H, Zdzienicka MZ. Inducibility of nuclear Rad51 foci after DNA damage distinguishes all Fanconi anemia complementation groups from D1/BRCA2. Mutat Res 2006;594:39-48. [PubMed: 16154163]

22. Gush KA, Fu KL, Grompe M, Walsh CE. Phenotypic correction of Fanconi anemia group C knockout mice. Blood 2000;95:700-4. [PubMed: 10627482]

23. Habi O, Delisle MC, Messier N, Carreau M. Lack of self-renewal capacity in Fancc-/- stem cells after ex vivo expansion. Stem Cells 2005;23:1135-41. [PubMed: 16020692]

24. Hadjur S, Jirik FR. Increased sensitivity of Fancc-deficient hematopoietic cells to nitric oxide and evidence that this species mediates growth inhibition by cytokines. Blood 2003;101:3877-84. [PubMed: 12521994]

25. Hadjur S, Ung K, Wadsworth L, Dimmick J, Rajcan-Separovic E, Scott RW, Buchwald M, Jirik FR. Defective hematopoiesis and hepatic steatosis in mice with combined deficiencies of the genes encoding Fancc and Cu/Zn superoxide dismutase. Blood 2001;98:1003-11. [PubMed: 11493445]

26. Haneline LS, Broxmeyer HE, Cooper S, Hangoc G, Carreau M, Buchwald M, Clapp DW. Multiple inhibitory cytokines induce deregulated progenitor growth and apoptosis in hematopoietic cells from Fac-/- mice. Blood 1998;91:4092-8. [PubMed: 9596654]

27. Haneline LS, Gobbett TA, Ramani R, Carreau M, Buchwald M, Yoder MC, Clapp DW. Loss of FancC function results in decreased hematopoietic stem cell repopulating ability. Blood 1999;94:18. [PubMed: 10381491]

28. Haneline LS, Li X, Ciccone SL, Hong P, Yang Y, Broxmeyer HE, Lee SH, Orazi A, Srour EF, Clapp DW. Retroviral-mediated expression of recombinant Fancc enhances the repopulating ability of Fancc-/- hematopoietic stem cells and decreases the risk of clonal evolution. Blood 2003;101:1299307. [PubMed: 12393504] 
29. Hogg N, Kalyanaraman B. Nitric oxide and lipid peroxidation. Biochim Biophys Acta 1999;1411:378-84. [PubMed: 10320670]

30. Houghtaling S, Granville L, Akkari Y, Torimaru Y, Olson S, Finegold M, Grompe M. Heterozygosity for p53 (Trp53+/-) accelerates epithelial tumor formation in fanconi anemia complementation group D2 (Fancd2) knockout mice. Cancer Res 2005;65:85-91. [PubMed: 15665282]

31. Houghtaling S, Newell A, Akkari Y, Taniguchi T, Olson S, Grompe M. Fancd2 functions in a double strand break repair pathway that is distinct from non-homologous end joining. Hum Mol Genet 2005;14:3027-33. [PubMed: 16135554]

32. Houghtaling S, Timmers C, Noll M, Finegold MJ, Jones SN, Meyn MS, Grompe M. Epithelial cancer in Fanconi anemia complementation group D2 (Fancd2) knockout mice. Genes Dev 2003;17:202135. [PubMed: 12893777]

33. Howlett NG, Taniguchi T, Durkin SG, D'Andrea AD, Glover TW. The Fanconi anemia pathway is required for the DNA replication stress response and for the regulation of common fragile site stability. Hum Mol Genet 2005;14:693-701. [PubMed: 15661754]

34. Howlett NG, Taniguchi T, Olson S, Cox B, Waisfisz Q, De Die-Smulders C, Persky N, Grompe M, Joenje H, Pals G, Ikeda H, Fox EA, D'Andrea AD. Biallelic inactivation of BRCA2 in Fanconi anemia. Science 2002;297:606-9. [PubMed: 12065746]

35. Huang TT, Nijman SM, Mirchandani KD, Galardy PJ, Cohn MA, Haas W, Gygi SP, Ploegh HL, Bernards R, D'Andrea AD. Regulation of monoubiquitinated PCNA by DUB autocleavage. Nat Cell Biol 2006;8:339-47. [PubMed: 16531995]

36. Kim JM, Parmar K, Huang M, Weinstock DM, Ruit CA, Kutok JL, D'Andrea AD. Inactivation of murine Usp1 results in genomic instability and a fanconi anemia phenotype. Dev Cell 2009;16:31420. [PubMed: 19217432]

37. Koomen M, Cheng NC, van de Vrugt HJ, Godthelp BC, van der Valk MA, Oostra AB, Zdzienicka MZ, Joenje H, Arwert F. Reduced fertility and hypersensitivity to mitomycin C characterize Fancg/ Xrcc9 null mice. Hum Mol Genet 2002;11:273-81. [PubMed: 11823446]

38. Krasnoshtein F, et al. Developmental expression of the Fac gene correlates with congenitcl defects in Fanconi anemia patients. Human Molecular Genetics 1996;5:85-93. [PubMed: 8789444]

39. Li J, Sejas DP, Zhang X, Qiu Y, Nattamai KJ, Rani R, Rathbun KR, Geiger H, Williams DA, Bagby GC, Pang Q. TNF-alpha induces leukemic clonal evolution ex vivo in Fanconi anemia group C murine stem cells. J Clin Invest 2007;117:3283-95. [PubMed: 17960249]

40. Li X, Le Beau MM, Ciccone S, Yang FC, Freie B, Chen S, Yuan J, Hong P, Orazi A, Haneline LS, Clapp DW. Ex vivo culture of Fancc-/- stem/progenitor cells predisposes cells to undergo apoptosis, and surviving stem/progenitor cells display cytogenetic abnormalities and an increased risk of malignancy. Blood 2005;105:3465-71. [PubMed: 15644418]

41. Li X, Plett PA, Yang Y, Hong P, Freie B, Srour EF, Orschell CM, Clapp DW, Haneline LS. Fanconi anemia type C-deficient hematopoietic stem/progenitor cells exhibit aberrant cell cycle control. Blood 2003;102:2081-4. [PubMed: 12763929]

42. Li X, Yang Y, Yuan J, Hong P, Freie B, Orazi A, Haneline LS, Clapp DW. Continuous in vivo infusion of interferon-gamma (IFN-gamma) preferentially reduces myeloid progenitor numbers and enhances engraftment of syngeneic wild-type cells in Fancc-/- mice. Blood 2004;104:1204-9. [PubMed: 15113761]

43. Li Y, Chen S, Yuan J, Yang Y, Li J, Ma J, Wu X, Freund M, Pollok K, Hanenberg H, Goebel WS, Yang FC. Mesenchymal stem/progenitor cells promote the reconstitution of exogenous hematopoietic stem cells in Fancg-/- mice in vivo. Blood 2009;113:2342-51. [PubMed: 19129541]

44. Maciejewski J, Selleri C, Anderson S, Young NS. Fas antigen expression on CD34+ human marrow cells is induced by interferon gamma and tumor necrosis factor alpha and potentiates cytokinemediated hematopoietic suppression in vitro. Blood 1995;85:3183-90. [PubMed: 7538820]

45. Marmorstein LY, Ouchi T, Aaronson SA. The BRCA2 gene product functionally interacts with p53 and RAD51. Proc Natl Acad Sci U S A 1998;95:13869-74. [PubMed: 9811893]

46. McAllister KA, Bennett LM, Houle CD, Ward T, Malphurs J, Collins NK, Cachafeiro C, Haseman J, Goulding EH, Bunch D, Eddy EM, Davis BJ, Wiseman RW. Cancer susceptibility of mice with a homozygous deletion in the COOH-terminal domain of the Brca2 gene. Cancer Res 2002;62:990 4. [PubMed: 11861370] 
47. McAllister KA, Houle CD, Malphurs J, Ward T, Collins NK, Gersch W, Wharey L, Seely JC, Betz L, Bennett LM, Wiseman RW, Davis BJ. Spontaneous and irradiation-induced tumor susceptibility in BRCA2 germline mutant mice and cooperative effects with a p53 germline mutation. Toxicol Pathol 2006;34:187-98. [PubMed: 16546942]

48. Meetei AR, de Winter JP, Medhurst AL, Wallisch M, Waisfisz Q, van de Vrugt HJ, Oostra AB, Yan Z, Ling C, Bishop CE, Hoatlin ME, Joenje H, Wang W. A novel ubiquitin ligase is deficient in Fanconi anemia. Nat Genet 2003;35:165-70. [PubMed: 12973351]

49. Moynahan ME, Pierce AJ, Jasin M. BRCA2 is required for homology-directed repair of chromosomal breaks. Mol Cell 2001;7:263-72. [PubMed: 11239455]

50. Muller LU, Milsom MD, Kim MO, Schambach A, Schuesler T, Williams DA. Rapid lentiviral transduction preserves the engraftment potential of Fanca(-/-) hematopoietic stem cells. Mol Ther 2008;16:1154-60. [PubMed: 18398427]

51. Nadler JJ, Braun RE. Fanconi anemia complementation group C is required for proliferation of murine primordial germ cells. Genesis 2000;27:117-23. [PubMed: 10951504]

52. Navarro S, Meza NW, Quintana-Bustamante O, Casado JA, Jacome A, McAllister K, Puerto S, Surralles J, Segovia JC, Bueren JA. Hematopoietic dysfunction in a mouse model for Fanconi anemia group D1. Mol Ther 2006;14:525-35. [PubMed: 16859999]

53. Niedernhofer LJ, Daniels JS, Rouzer CA, Greene RE, Marnett LJ. Malondialdehyde, a product of lipid peroxidation, is mutagenic in human cells. J Biol Chem 2003;278:31426-33. [PubMed: 12775726]

54. Niedernhofer LJ, Odijk H, Budzowska M, van Drunen E, Maas A, Theil AF, de Wit J, Jaspers NG, Beverloo HB, Hoeijmakers JH, Kanaar R. The structure-specific endonuclease Ercc1-Xpf is required to resolve DNA interstrand cross-link-induced double-strand breaks. Mol Cell Biol 2004;24:577687. [PubMed: 15199134]

55. Nijman SM, Huang TT, Dirac AM, Brummelkamp TR, Kerkhoven RM, D'Andrea AD, Bernards R. The Deubiquitinating Enzyme USP1 Regulates the Fanconi Anemia Pathway. Mol Cell 2005;17:331-9. [PubMed: 15694335]

56. Noll M, Battaile KP, Bateman R, Lax TP, Rathbun K, Reifsteck C, Bagby G, Finegold M, Olson S, Grompe M. Fanconi anemia group A and C double-mutant mice: functional evidence for a multiprotein Fanconi anemia complex. Exp Hematol 2002;30:679-88. [PubMed: 12135664]

57. Oestergaard VH, Langevin F, Kuiken HJ, Pace P, Niedzwiedz W, Simpson LJ, Ohzeki M, Takata M, Sale JE, Patel KJ. Deubiquitination of FANCD2 is required for DNA crosslink repair. Mol Cell 2007;28:798-809. [PubMed: 18082605]

58. Otsuki T, Nagakura S, Wang J, Bloom M, Grompe M, Liu JM. Tumor necrosis factor-alpha and CD95 ligation suppress erythropoiesis in Fanconi anemia C gene knockout mice. J Cell Physiol 1999;179:79-86. [PubMed: 10082135]

59. Pang Q, Fagerlie S, Christianson TA, Keeble W, Faulkner G, Diaz J, Rathbun RK, Bagby GC. The Fanconi anemia protein FANCC binds to and facilitates the activation of STAT1 by gamma interferon and hematopoietic growth factors. Mol Cell Biol 2000;20:4724-35. [PubMed: 10848598]

60. Pang Q, Keeble W, Christianson TA, Faulkner GR, Bagby GC. FANCC interacts with Hsp70 to protect hematopoietic cells from IFN-gamma/TNF-alpha-mediated cytotoxicity. EMBO J 2001;20:4478-89. [PubMed: 11500375]

61. Rani R, Li J, Pang Q. Differential p53 engagement in response to oxidative and oncogenic stresses in Fanconi anemia mice. Cancer Res 2008;68:9693-702. [PubMed: 19047147]

62. Rathbun RK, Faulkner GR, Ostroski MH, Christianson TA, Hughes G, Jones G, Cahn R, Maziarz R, Royle G, Keeble W, Heinrich MC, Grompe M, Tower PA, Bagby GC. Inactivation of the Fanconi anemia group $\mathrm{C}$ gene augments interferon-gamma-induced apoptotic responses in hematopoietic cells. Blood 1997;90:974-85. [PubMed: 9242526]

63. Reid S, Schindler D, Hanenberg H, Barker K, Hanks S, Kalb R, Neveling K, Kelly P, Seal S, Freund M, Wurm M, Batish SD, Lach FP, Yetgin S, Neitzel H, Ariffin H, Tischkowitz M, Mathew CG, Auerbach AD, Rahman N. Biallelic mutations in PALB2 cause Fanconi anemia subtype FA-N and predispose to childhood cancer. Nat Genet 2007;39:162-4. [PubMed: 17200671]

64. Ridpath JR, Nakamura A, Tano K, Luke AM, Sonoda E, Arakawa H, Buerstedde JM, Gillespie DA, Sale JE, Yamazoe M, Bishop DK, Takata M, Takeda S, Watanabe M, Swenberg JA, Nakamura J. 
Cells deficient in the FANC/BRCA pathway are hypersensitive to plasma levels of formaldehyde. Cancer Res 2007;67:11117-22. [PubMed: 18056434]

65. Rio P, Meza NW, Gonzalez-Murillo A, Navarro S, Alvarez L, Surralles J, Castella M, Guenechea G, Segovia JC, Hanenberg H, Bueren JA. In vivo proliferation advantage of genetically corrected hematopoietic stem cells in a mouse model of Fanconi anemia FA-D1. Blood 2008;112:4853-61. [PubMed: 18812474]

66. Rio P, Segovia JC, Hanenberg H, Casado JA, Martinez J, Gottsche K, Cheng NC, Van de Vrugt HJ, Arwert F, Joenje H, Bueren JA. In vitro phenotypic correction of hematopoietic progenitors from Fanconi anemia group A knockout mice. Blood 2002;100:2032-9. [PubMed: 12200363]

67. Rosselli F, Sanceau J, Gluckman E, Wietzerbin J, Moustacchi E. Abnormal lymphokine production: a novel feature of the genetic disease Fanconi anemia. II. In vitro and in vivo spontaneous overproduction of tumor necrosis factor alpha. Blood 1994;83:1216-25. [PubMed: 8118026]

68. Schultz JC, Shahidi NT. Tumor necrosis factor-alpha overproduction in Fanconi's anemia. Am J Hematol 1993;42:196-201. [PubMed: 8438880]

69. Sejas DP, Rani R, Qiu Y, Zhang X, Fagerlie SR, Nakano H, Williams DA, Pang Q. Inflammatory reactive oxygen species-mediated hemopoietic suppression in Fancc-deficient mice. J Immunol 2007;178:5277-87. [PubMed: 17404312]

70. Sharan SK, Morimatsu M, Albrecht U, Lim DS, Regel E, Dinh C, Sands A, Eichele G, Hasty P, Bradley A. Embryonic lethality and radiation hypersensitivity mediated by Rad51 in mice lacking Brca2. Nature 1997;386:804-10. [PubMed: 9126738]

71. Shen SX, Weaver Z, Xu X, Li C, Weinstein M, Chen L, Guan XY, Ried T, Deng CX. A targeted disruption of the murine Brcal gene causes gamma-irradiation hypersensitivity and genetic instability. Oncogene 1998;17:3115-24. [PubMed: 9872327]

72. Si Y, Ciccone S, Yang FC, Yuan J, Zeng D, Chen S, van de Vrugt HJ, Critser J, Arwert F, Haneline LS, Clapp DW. Continuous in vivo infusion of interferon-gamma (IFN-gamma) enhances engraftment of syngeneic wild-type cells in Fanca-/- and Fancg-/- mice. Blood 2006;108:4283-7. [PubMed: 16946306]

73. Sii-Felice K, Barroca V, Etienne O, Riou L, Hoffschir F, Fouchet P, Boussin FD, Mouthon MA. Role of fanconi DNA repair pathway in neural stem cell homeostasis. Cell Cycle 2008;7:1911-5. [PubMed: 18604174]

74. Sii-Felice K, Etienne O, Hoffschir F, Mathieu C, Riou L, Barroca V, Haton C, Arwert F, Fouchet P, Boussin FD, Mouthon MA. Fanconi DNA repair pathway is required for survival and long-term maintenance of neural progenitors. Embo J 2008;27:770-81. [PubMed: 18239686]

75. Skinner AM, O'Neill SL, Grompe M, Kurre P. CXCR4 induction in hematopoietic progenitor cells from Fanca(-/-), -c(-/-), and -d2(-/-) mice. Exp Hematol 2008;36:273-82. [PubMed: 18279715]

76. Smogorzewska A, Matsuoka S, Vinciguerra P, McDonald ER 3rd, Hurov KE, Luo J, Ballif BA, Gygi SP, Hofmann K, D'Andrea AD, Elledge SJ. Identification of the FANCI Protein, a Monoubiquitinated FANCD2 Paralog Required for DNA Repair. Cell 2007;129:289-301. [PubMed: 17412408]

77. Tarsounas M, Davies D, West SC. BRCA2-dependent and independent formation of RAD51 nuclear foci. Oncogene 2003;22:1115-23. [PubMed: 12606939]

78. Tutt A, Bertwistle D, Valentine J, Gabriel A, Swift S, Ross G, Griffin C, Thacker J, Ashworth A. Mutation in Brca2 stimulates error-prone homology-directed repair of DNA double-strand breaks occurring between repeated sequences. EMBO J 2001;20:4704-16. [PubMed: 11532935]

79. van de Vrugt HJ, Cheng NC, de Vries Y, Rooimans MA, de Groot J, Scheper RJ, Zhi Y, Hoatlin ME, Joenje H, Arwert F. Cloning and characterization of murine fanconi anemia group A gene: Fanca protein is expressed in lymphoid tissues, testis, and ovary. Mamm Genome 2000;11:326-31. [PubMed: 10754110]

80. Wang X, Andreassen PR, D'Andrea AD. Functional interaction of monoubiquitinated FANCD2 and BRCA2/FANCD1 in chromatin. Mol Cell Biol 2004;24:5850-62. [PubMed: 15199141]

81. Wevrick R, Clarke CA, Buchwald M. Cloning and analysis of the murine Fanconi anemia group C cDNA. Hum Mol Genet 1993;2:655-62. [PubMed: 7689006]

82. Whitney MA, Royle G, Low MJ, Kelly MA, Axthelm MK, Reifsteck C, Olson S, Braun RE, Heinrich MC, Rathbun RK, Bagby GC, Grompe M. Germ cell defects and hematopoietic hypersensitivity to 
gamma-interferon in mice with a targeted disruption of the Fanconi anemia $\mathrm{C}$ gene. Blood 1996;88:49-58. [PubMed: 8704201]

83. Wong JC, Alon N, McKerlie C, Huang JR, Meyn MS, Buchwald M. Targeted disruption of exons 1 to 6 of the Fanconi Anemia group A gene leads to growth retardation, strain-specific microphthalmia, meiotic defects and primordial germ cell hypoplasia. Hum Mol Genet 2003;12:2063-76. [PubMed: 12913077]

84. Wong JC, Alon N, Norga K, Kruyt FA, Youssoufian H, Buchwald M. Cloning and analysis of the mouse Fanconi anemia group A cDNA and an overlapping penta zinc finger cDNA. Genomics 2000;67:273-83. [PubMed: 10936049]

85. Yamada K, Ramezani A, Hawley RG, Ebell W, Arwert F, Arnold LW, Walsh CE. Phenotype correction of Fanconi anemia group A hematopoietic stem cells using lentiviral vector. Mol Ther 2003;8:600-10. [PubMed: 14529833]

86. Yang Y, Kuang Y, Montes De Oca R, Hays T, Moreau L, Lu N, Seed B, D'Andrea AD. Targeted disruption of the murine Fanconi anemia gene, Fancg/Xrcc9. Blood 2001;98:3435-40. [PubMed: 11719385]

87. Yang YG, Herceg Z, Nakanishi K, Demuth I, Piccoli C, Michelon J, Hildebrand G, Jasin M, Digweed M, Wang ZQ. The Fanconi anemia group A protein modulates homologous repair of DNA doublestrand breaks in mammalian cells. Carcinogenesis 2005;26:1731-40. [PubMed: 15905196]

88. Zhang QS, Eaton L, Snyder ER, Houghtaling S, Mitchell JB, Finegold M, Van Waes C, Grompe M. Tempol protects against oxidative damage and delays epithelial tumor onset in Fanconi anemia mice. Cancer Res 2008;68:1601-8. [PubMed: 18316625]

89. Zhang X, Li J, Sejas DP, Pang Q. Hypoxia-reoxygenation induces premature senescence in FA bone marrow hematopoietic cells. Blood 2005;106:75-85. [PubMed: 15769896]

90. Zhang X, Li J, Sejas DP, Rathbun KR, Bagby GC, Pang Q. The Fanconi anemia proteins functionally interact with the protein kinase regulated by RNA (PKR). J Biol Chem 2004;279:43910-9. [PubMed: 15299030]

91. Zhang X, Sejas DP, Qiu Y, Williams DA, Pang Q. Inflammatory ROS promote and cooperate with the Fanconi anemia mutation for hematopoietic senescence. J Cell Sci 2007;120:1572-83. [PubMed: 17405815] 


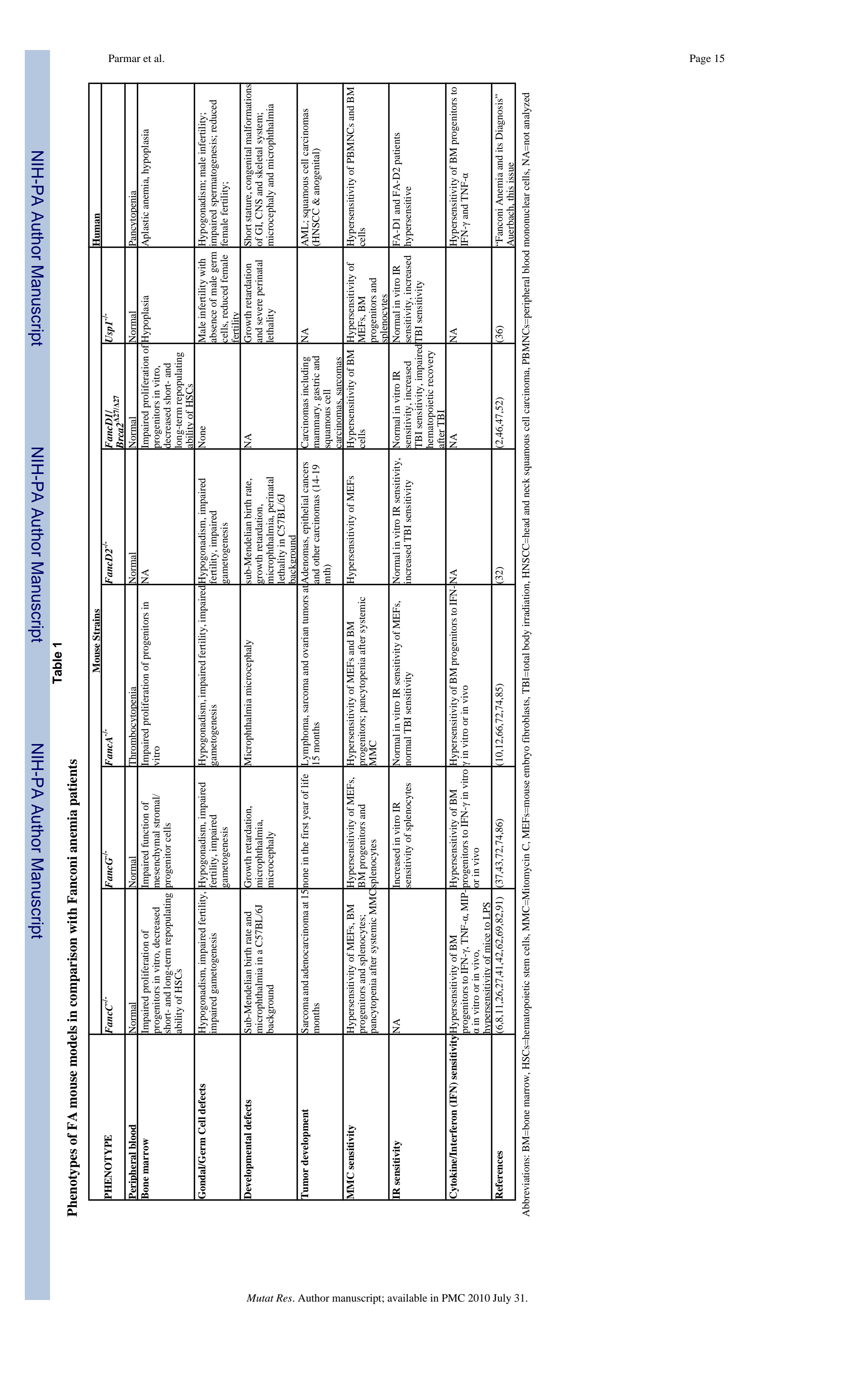

